\title{
Effect of Spacings and Varieties on Yield Attributes and Fruit Yield of Okra (Abelmoschus esculentus (L.) Moench.)
}

\author{
Pankaj Kumar Singh, A. K. Pal, Ajay Kumar Tiwari" and Trivikram \\ Department of Horticulture, Institute of Agricultural Sciences, \\ BHU, Varanasi-221005 (UP), India \\ *Corresponding author
}

\section{A B S T R A C T}

Optimum plant density along with suitable varieties plays a significant role with respect to the growth, yield, and quality in okra. The present experiment was conducted to assess the suitable combinations of different varieties and planting distances and their effects on

\section{Keywords}

Optimum plant density, Okra, Planting distance

\section{Article Info}

Accepted:

15 July 2020

Available Online:

10 August 2020 various quantitative and qualitative attributes of okra at Vegetable Research Farm, Institute of Agricultural Sciences, BHU, Varanasi. Variety Kashi Pragati perform well at spacing $(45 \times 45 \mathrm{~cm})$ in respect to total yield as compare to other variety and spacing. Branches are more seen when plant sown at wider spacing $(45 \times 60 \mathrm{~cm})$. There are different parameters performed well at different spacing to different variety. In this experiment it is found that the number of seed per pod found better among close spacing $(45 \times 30 \mathrm{~cm})$ as compare to other spacing. Among different variety, Kashi Kranti produce more number of seed per pod as compare to other variety. Seeds weight of variety Pusa Sawani is more at wider spacing $(45 \times 60 \mathrm{~cm})$ as compare to other variety and spacing. At last it is concluded that spacing $(45 \times 45 \mathrm{~cm})$ are best spacing for okra sowing because the plant gets optimum space for proper growth, at spacing $(45 \times 30 \mathrm{~cm})$ there is competition for nutrient, light etc., at spacing $(45 \times 60 \mathrm{~cm})$ there is lesser plant population ultimately lead to yield reduction. Variety Kashi Pragati performs better as compare to other variety. In respect to farmer benefit from this trail it is concluded that optimum spacing and varities play important role for farmer benefit. Due to optimum spacing there are less competition between plant for nutrient, moisture, and light and it also help in proper weeding between the plan and ultimately to increased yield. The cost of cultivation is also reduced leading to enhanced profit.

\section{Introduction}

It is one of the most significant vegetable crops which are grown throughout the tropical, subtropical and temperate region of the world. The immature, young green seed pods are the edible part which consumed as vegetable purpose. Young leaves can be cooked, eaten and the flowers are also edible. It could generate better price in the market and plays very significant role in improving the farmers income.

The fresh okra fruit consists of water $90 \%$, energy $38 \mathrm{Kcal}$, protein $2 \%$, fat $0.1 \mathrm{~g}$, carbohydrate $7.6 \mathrm{~g}$, fibre $0.9 \mathrm{~g}, \mathrm{Ca} 66 \mathrm{mg}, \mathrm{P}$ 
$103 \mathrm{mg}, \mathrm{Fe} 0.8 \mathrm{mg}$, Na $8 \mathrm{mg}, \mathrm{K} 303 \mathrm{mg}$, vitamin A $660 \mathrm{IU}$, thiamine $0.20 \mathrm{mg}$, riboflavin $0.06 \mathrm{mg}$, niacin $1 \mathrm{mg}$, ascorbic acid $21.1 \mathrm{mg}$ and vitamin $\mathrm{B}_{6} 0.22 \mathrm{mg}$ per $100 \mathrm{~g}$ of edible portion (Haytowitz and Matthews, 1984). The fibre obtained from okra stem is used in paper industry (Martin, 1982 and Bell, 1988). The ripe seed of okra are sometimes roasted and ground as a coffee substitute, while the seed powder has been used as substitute for the aluminium salts for water purification (Vaidya and Nanoti, 1989). Okra provides an important source of vitamins, calcium, potassium and other mineral matters, which are often lacking in the diet in developing countries. Its medicinal values have been also reported in curing ulcers and relief from haemorrhoids (Adams, 1975).

The yield of okra is affected by many agronomical, ecological and edaphic factors like variety, environment, soil fertility, plant spacing, per unit area plant populations and cultural practices. Spacing is one of the very basic management practice prescribed for almost all the commercial crops. Plant density has a profound influence on plant growth, development, architecture and yield of many crops (Stoffella and Bryan, 1998). Proper spacing leads to optimum canopy exposure to light and also it provides uniform area for water and mineral uptake by roots. The several reasons for poor growth and yield of okra, among those, intra row spacing is playing an important role (Yadav and Dhanhar, 2005). Spacing determines the available area for a plant to source for growth recourses, such as water, light and nutrients. (Absar and Siddique, 1982) noted that plant density is another important factor that affects okra seed production. The optimum spacing provides better condition for plant growth, which results in timely commencement of reproductive phase and formation of more fruits. The suitable plant spacing can lead to optimum seed yield while too high or too low plant spacing could result to relatively low yield and quality.

Spacing okra optimally reduced plant competition for light, moisture and nutrient wider or narrow spacing may lead to reduction in yield. Some varieties of okra are taller in height, while other are dwarf, because of this there is variation in their performance (Dikwahal et al., 2006). Farmers of India generally do not use any special technique for quality production of okra. Among the cultural practices, the spacing allowed to individual plant is one of the most important factor which control their development and yield. Proper plant spacing can lead to optimum fruit and seed yield whereas too high or low plant spacing could result in relatively low yields (Amjad et al., 2002). Day by day the population of India is increasing, so demands of vegetables are naturally increasing. The density of plant population is an important factor, which affect the growth, yield and quality of the crops, by efficient utilization of field condition. It also determine optimum seed rate and improve the value of seed economy. Plant spacing has been found to have an enhancing influence on yield ability and quality of seed. The closer spacing in okra especially during rainy season pose greater problems of manual weeding and hoeing by adjusting the row and plant spacing without affecting the yield and quality of seed and, therefore, the optimum spacing needs to be worked out. Adoption of optimum plant geometry facilitates efficient absorption of nutrients and adequate trapping of solar energy to have a positive effect on fruit yield. Further, it was reported that optimum plant population is the key element for higher yields, as plant growth and yield are affected by intra and inter row spacing (Amjad et al., 2002). The improper plant spacing may cause either too dense or too sparse population resulting in the reduction of okra yield. But optimum plant densities ensure the plant to 
grow uniformly and properly through efficient utilization of moisture, nutrient, light and thus cause to produce maximum yield of okra. Planting with proper spacing increases yield quality and size of fruit.

Keeping in view the consideration an experiment entitled "Effect of spacings and varieties on yield attributes and fruit yield of okra [Abelmoschus esculentus (L.) Moench.]" was formulated and conducted during rainy season-2017 at Horticultural Research Farm, Department of Horticulture, Institute of Agricultural Sciences, Banaras Hindu University, Varanasi-221005 with the following objectives include to determined the optimum spacing for high fruit yield in okra and also to see the effect of plant spacing on different varieties of okra to give the higher fruit yield.

\section{Materials and Methods}

The research work was conducted at Vegetable Research Farm, Department of Horticulture, Institute of Agricultural Sciences, Banaras Hindu University, Varanasi during rainy season 2017. The experimental field was well drained with uniform topography and having assured source of water supply. Harrowing and planking were done before the execution of layout of the experimental field. Proper ploughing was performed in order to bring fine tilth. 27 plots, each of $2.5 \times 2.5 \mathrm{~m}^{2}$ size were prepared. The seeds were planted on raised ridges with different variety and planting spacings. About two to three seeds were sown at one place then thinning of seedlings was performed maintaining one plant per stand after germination. Fertilizers were applied as per the recommendation i.e., 100:60:50 $\mathrm{kg} \mathrm{N}$, $\mathrm{P}_{2} \mathrm{O}_{5}$, and $\mathrm{K}_{2} \mathrm{O}$. As per the need, the experimental plots were irrigated during the cropping period. Four weedings were practiced as per the requirement with the view to maintain the proper growth of the crop. Five plants from the total population were randomly selected for recording of the observations.

The various yield and qualitative parameters taken under study are days to $50 \%$ flowering, node at which first flower appears, days to first fruit setting, fruit length $(\mathrm{cm})$, fruit width (cm), number of fruits per plant, average fruit weight $(\mathrm{g})$, fruit yield per plant $(\mathrm{kg})$, and fruit yield (q/ha). The observations recorded were summed up and divided by five to get the mean value. The experiment was laid out in Randomized Complete Block Design with three replications. Three sowing variety i.e., Kashi Kranti $\left(\mathrm{V}_{1}\right)$, Kashi Pragati $\left(\mathrm{V}_{2}\right)$, and Pusa Sawani $\left(\mathrm{V}_{3}\right)$ and three spacing i.e., 45 $\times 30 \mathrm{~cm}\left(\mathrm{~S}_{1}\right), 45 \times 45 \mathrm{~cm}\left(\mathrm{~S}_{2}\right)$, and $45 \times 60 \mathrm{~cm}$ $\left(\mathrm{S}_{3}\right)$ and their combinations were practiced at both the locations. Statistical analysis of data collected was based on the procedure for Randomized Complete Block Design (RCBD) for factorial experiment as outlined by Steel and Torrie (1980).

\section{Results and Discussion}

Fresh weight of fruit was significantly increased to various spacing, variety and its interaction. The maximum fresh weight of fruit (13.37 g) was noted at a spacing of $45 \times 45 \mathrm{~cm}$ and it was maximum (12.45 g) in variety Kashi Kranti. In case of interaction, significant effects are seen on the fresh weight of fruit and it was maximum $(13.84 \mathrm{~g})$ recorded under treatment $T_{5}$. The result obtained that are close confirmative to finding of Firoz et al., (2007) and Jana et al., (2010). The fresh weight of fruit are increased with increase in spacing due to widest spacing might be due to more accumulation of dry matter on fruit by the plant.

Length of fruit was significantly varies due to different spacing and variety that are adopted. 
The maximum length of fruit $(12.02 \mathrm{~cm})$ was obtained at spacing $45 \times 60 \mathrm{~cm}$ and it was maximum $(13.03 \mathrm{~cm})$ was recorded in variety Kashi Pragati. The spacing $\mathrm{S}_{3}$ are statistically at par with spacing $S_{2}(11.76 \mathrm{~cm})$. In case of interaction maximum $(13.85 \mathrm{~cm})$ length of fruit was recorded in treatment $\mathrm{T}_{5}$ which was statistically at par with treatment $\mathrm{T}_{8}(13.56$ $\mathrm{cm})$. This result is close confirmative to finding of result of Madisa et al., (2015) and Firoz et al., (2007). The results of present study are in interaction with Singh (1990) who reported that maximum fruit length was obtained at wider spacings due to the abundance of growth factors such as space and moisture which have been favoured towards the low plant population. Diameter of fruit was non-significant effect was seen to different spacing and its interaction The maximum diameter of fruit $(1.39 \mathrm{~cm})$ was recorded at spacing $45 \times 60 \mathrm{~cm}$ and it was maximum $(1.40 \mathrm{~cm})$ in variety Pusa Sawani and it was statistically at par with Kashi Pragati. The diameter of fruit are increased with increase in spacing due to widest spacing might be due to more accumulation of dry matter by the plant. This result is in accordance with that of Palanisamy et al., (1986). They found that fruit length increase with decrease plant density at fixed level.

Average dry weight of 8 fruits was nonsignificant in respect of spacing and had significant effect seen on average dry weight of 8 fruits in respect of variety. It was maximum $(11.50 \mathrm{~g})$ in a spacing of $45 \times 60 \mathrm{~cm}$ and it was also maximum (11.79 g) recorded in variety (Pusa Sawani). Which was statistically at par with variety Kashi Pragati as for interaction effect maximum (12.07 g) was recorded under treatment $\mathrm{T}_{9}$.

Length of mature fruit was significantly affected due to different spacing and variety that are adopted. The length of mature fruit was maximum $(14.59 \mathrm{~cm})$ at a spacing $45 \times 60$ $\mathrm{cm}$ and it was maximum $(14.43 \mathrm{~cm})$ was recorded Kashi Pragati. The spacing $\mathrm{S}_{3}$ are statistically at par with spacing $\mathrm{S}_{2}$ and variety Kashi Pragati was statistically at par with variety Pusa Sawani. In case of interaction effect it was maximum $(15.09 \mathrm{~cm})$ in treatment $\mathrm{T}_{5}$ which was statistically at par with treatment $T_{8}$. The length of mature fruit are increased with optimum spacing there are less inter competition between the plant for nutrient, moisture and light. Individual fruit weight also plays a key role in determining the yield per plant or per unit area. This result is in accordance with that of Yohanna et al., (2014), Baw (2014), Sonu et al., (2013), Ekwu and Nwokwu (2012).

Weight of mature fruit was significantly increased to various spacing and variety taken to assume. There are significant effect of spacing and variety are observed on the weight of mature fruit. The maximum weight of mature fruit (26.85 g) was noted at spacing of $45 \times 60 \mathrm{~cm}$ and in case of variety it was maximum $(27.01 \mathrm{~g})$ in variety Pusa Sawani. The spacing $45 \times 60 \mathrm{~cm}$ was statistically at par with spacing $S_{2}$. In case of interaction, significant effects are seen on the weight of mature fruit and maximum (26.01 g) was recorded under treatment $T_{2}, T_{5}$ and $T_{8}$. The weight of mature fruit are increased with increase in spacing might be due to more accumulation of dry matter on fruit by the plant. This result is in accordance with that of Yohanna et al., (2014).

Diameter of mature fruit was significant effect seen on different variety and spacing. The maximum diameter of mature fruit (2.16 $\mathrm{cm}$ ) was noted in a spacing of $45 \times 60 \mathrm{~cm}$ and it was maximum $(2.18 \mathrm{~cm})$ in Pusa Sawani. There are non- significant effects of spacing and variety on the diameter of mature fruit. The maximum $(2.20 \mathrm{~cm})$ diameter of mature fruit was observed under treatment $\mathrm{T}_{9}$. The diameter of mature fruit are increased with 
increase in spacing due to widest spacing might be due to more accumulation of dry matter by the plant (Yohanna et al., 2014, Ekwu and Nwokwu, 2012).

Number of fruits per plant is an important yield attributed of okra because higher number of fruits per plant produces the higher yield. Number of fruits per plant was significantly increased due to various spacing and variety adopted. There was significant effect seen on the various varieties, spacing and its interaction. The maximum 16.58) number of fruits per plant was obtained at a spacing $45 \times 60 \mathrm{~cm}$ and it was maximum (16.65) in variety Kashi Kranti. The spacing $\mathrm{S}_{3}$ was statistically at par with $\mathrm{S}_{2}$. In case of interaction maximum (17.24) seen in treatment $\mathrm{T}_{9}, \mathrm{~T}_{6}$ and $\mathrm{T}_{3}$ respectively. The result was close confirmative to finding of Sonu et al., (2013) and Firoz et al., (2007) and Palanisamy et al., (1986) also stated that wider spacing slightly increased the number of fruits per plant. Reduced number of plant per unit area under wider spacing got less inter and intra plant competition. which cause increase in number of fruit per plant The number of fruits was more obtained in wider spacing due to proper availability of nutrient, moisture, sunlight and having proper spacing for its growth.

Weight of fruit per plant was significantly increased due to various spacing and variety. There was significant effect seen on the various varieties, spacing and its interaction effect. The maximum (245.43 g) weight of fruit per plant was recorded in spacing $45 \times 60$ cm which was statistically at par with $S_{2}$. It was maximum (239.05 g) recorded in variety Kashi Kranti. In case of interaction maximum $(287.34 \mathrm{~g})$ weight of fruit per plant was recorded in treatment $\mathrm{T}_{8}$ which was statistically at par with $\mathrm{T}_{5}$. Similar results were also reported by Shaha et al., (1989), Rehmans et al., (1994) and Parmar et al.,
(2015). The weight of fruit per plant are increased with increase in spacing due to widest spacing might be due to more accumulation of dry matter by the plant.

Weight of fruit per plot was significantly increased due to various spacing, variety and its interaction effect. There was significant effect seen on the various varieties, spacing and its interaction. The maximum $(8.74 \mathrm{~kg})$ weight of fruit per plot was recorded in spacing $45 \times 45 \mathrm{~cm}$ which was statistically at par with $\mathrm{S}_{1}$.

It was maximum $(8.92 \mathrm{~kg})$ recorded in variety Kashi Kranti. In case of interaction maximum $(10.06 \mathrm{~kg})$ weight of fruit per plot was recorded in treatment $\mathrm{T}_{5}$ which was statistically at par with $\mathrm{T}_{3}$. The weight of fruit per plot are increased with increase in spacing due to widest spacing might be due to more accumulation of dry matter by the plant. Khan and Jaiswal (1988), mondal et al., (1989), Singh et al., (1988), Singh et al., (2012) and Yohanna et al., (2014) reported higher yield of okra per hectare at closer spacing.

Number of seeds per pod was significantly increased due to various spacing and variety taken to assume. The maximum (59.93) number of seeds per pod was observed in spacing $45 \times 30 \mathrm{~cm}$ and it was maximum (59.53) was founded in variety Kashi Kranti which was statistically at par with Kashi Pragati (59.12). There are significant effect was seen in case of interaction the maximum (62.68) number of seeds per pod was found in treatment $\mathrm{T}_{1}\left(\mathrm{~S}_{1} \mathrm{~V}_{1}\right)$. The number of seeds per pod was found maximum at closer spacing. Similar findings were also reported by Sonu et al., (2013) and El-Waraky (2014)

Weight of 100 seeds was non-significantly increased to a various spacing and variety. There was non-significant effect of spacing and variety on weight of 100 seeds. The 
maximum $(7.19 \mathrm{~g})$ weight of 100 seeds found at a spacing $45 \times 60 \mathrm{~cm}$ and in respect to variety. It was maximum (7.62 g) was noted in variety Pusa Sawani. In case of interaction maximum $(7.72$ g) $\quad$ w recorded under treatment $T_{9}$. This could be attributed to the fact that at lower plant spacing there was intense competition among the plant while wider spacing vegetative production was stimulated at the expense of seed to a healthy seed production. Similar findings were also reported by Parmar et al., (2015) (Table 1 and 2).

Table.1 Effect of spacings and varieties on fresh weight of fruit $(\mathrm{g})$, length of fruit $(\mathrm{cm})$ and diameter of fruit $(\mathrm{cm})$, average dry weight of 8 fruits $(\mathrm{g})$, length of mature fruit $(\mathrm{cm})$ and weight of mature fruit $(\mathrm{g})$ of okra

\begin{tabular}{|c|c|c|c|c|c|c|}
\hline Treatments & $\begin{array}{l}\text { Fresh weight of } \\
\text { fruit(g) }\end{array}$ & $\begin{array}{c}\text { Length } \\
\text { of fruit } \\
\text { (cm) }\end{array}$ & $\begin{array}{c}\text { Diameter } \\
\text { of fruit } \\
\text { (cm) }\end{array}$ & $\begin{array}{c}\text { Average dry } \\
\text { weight of } 8 \\
\text { fruits (g) }\end{array}$ & $\begin{array}{l}\text { Length of } \\
\text { mature } \\
\text { fruit }(\mathrm{cm})\end{array}$ & $\begin{array}{c}\text { Weight of } \\
\text { mature } \\
\text { fruit (g) }\end{array}$ \\
\hline $\mathbf{T}_{1}\left(\mathbf{S}_{1} \mathbf{V}_{1}\right)$ & 10.33 & 10.59 & 1.35 & 9.45 & 13.29 & 24.31 \\
\hline $\mathbf{T}_{2}\left(\mathbf{S}_{1} \mathbf{V}_{2}\right)$ & 10.67 & 11.72 & 1.36 & 11.35 & 13.21 & 26.01 \\
\hline $\mathbf{T}_{\mathbf{3}}\left(\mathbf{S}_{\mathbf{1}} \mathbf{V}_{\mathbf{3}}\right)$ & 10.93 & 8.94 & 1.37 & 11.65 & 13.73 & 25.55 \\
\hline $\mathbf{T}_{4}\left(\mathbf{S}_{2} \mathbf{V}_{1}\right)$ & 13.74 & 11.58 & 1.35 & 10.71 & 14.18 & 24.31 \\
\hline $\mathbf{T}_{5}\left(\mathbf{S}_{2} \mathbf{V}_{2}\right)$ & 13.84 & 13.80 & 1.36 & 11.58 & 15.09 & 26.01 \\
\hline $\mathbf{T}_{6}\left(\mathbf{S}_{2} \mathbf{V}_{3}\right)$ & 12.53 & 9.91 & 1.37 & 11.65 & 14.03 & 25.55 \\
\hline $\mathbf{T}_{7}\left(\mathbf{S}_{3} \mathbf{V}_{1}\right)$ & 13.55 & 12.86 & 1.35 & 10.93 & 14.34 & 24.31 \\
\hline $\mathbf{T}_{\mathbf{8}}\left(\mathbf{S}_{\mathbf{3}} \mathbf{V}_{2}\right)$ & 13.49 & 13.56 & 1.36 & 11.50 & 15.01 & 26.01 \\
\hline $\mathbf{T}_{\mathbf{9}}\left(\mathbf{S}_{3} \mathbf{V}_{3}\right)$ & 12.38 & 9.49 & 1.37 & 12.07 & 14.42 & 25.55 \\
\hline C.D at $5 \%$ & 0.84 & 0.76 & ns & ns & 0.711 & ns \\
\hline
\end{tabular}

Table.2 Effect of spacings and varieties on diameter of mature fruit $(\mathrm{cm})$, number of fruit per plant and weight of fruit per plant $(\mathrm{g})$, weight of fruit per plot $(\mathrm{kg})$, number of seeds per pod and weight of 100 seeds $(\mathrm{g})$ of okra

\begin{tabular}{|c|c|c|c|c|c|c|}
\hline Treatments & $\begin{array}{c}\text { Number of } \\
\text { seeds per pod }\end{array}$ & $\begin{array}{l}\text { Number of } \\
\text { fruit per } \\
\text { plant }\end{array}$ & $\begin{array}{l}\text { Weight of } \\
\text { fruit per } \\
\text { plant (g) }\end{array}$ & $\begin{array}{l}\text { Weight of } \\
\text { fruit per } \\
\text { plot }(\mathrm{kg})\end{array}$ & $\begin{array}{l}\text { Diameter } \\
\text { of mature } \\
\text { fruit }(\mathrm{cm})\end{array}$ & $\begin{array}{l}\text { Weight } 100 \\
\text { seeds (g) }\end{array}$ \\
\hline $\mathbf{T}_{1}\left(\mathbf{S}_{1} \mathbf{V}_{1}\right)$ & 62.68 & 14.03 & 144.94 & 7.82 & 2.08 & 6.52 \\
\hline $\mathbf{T}_{2}\left(\mathbf{S}_{1} \mathbf{V}_{2}\right)$ & 59.45 & 16.40 & 150.23 & 8.11 & 2.06 & 6.55 \\
\hline $\mathbf{T}_{3}\left(\mathbf{S}_{1} \mathbf{V}_{3}\right)$ & 57.67 & 17.24 & 185.27 & 9.37 & 2.18 & 7.54 \\
\hline $\mathbf{T}_{4}\left(\mathbf{S}_{2} \mathbf{V}_{1}\right)$ & 59.38 & 14.03 & 225.52 & 9.16 & 2.10 & 6.83 \\
\hline $\mathbf{T}_{5}\left(\mathbf{S}_{2} \mathbf{V}_{2}\right)$ & 58.92 & 16.40 & 279.59 & 10.06 & 2.09 & 6.93 \\
\hline $\mathbf{T}_{6}\left(\mathbf{S}_{2} \mathbf{V}_{3}\right)$ & 55.54 & 17.24 & 194.52 & 7.00 & 2.16 & 7.60 \\
\hline $\mathbf{T}_{7}\left(\mathbf{S}_{3} \mathbf{V}_{1}\right)$ & 56.54 & 14.03 & 250.75 & 7.51 & 2.13 & 6.87 \\
\hline $\mathbf{T}_{\mathbf{8}}\left(\mathbf{S}_{\mathbf{3}} \mathbf{V}_{2}\right)$ & 59.01 & 16.40 & 287.34 & 8.61 & 2.14 & 6.98 \\
\hline $\mathbf{T}_{9}\left(\mathbf{S}_{3} \mathbf{V}_{3}\right)$ & 56.98 & 17.24 & 198.19 & 5.94 & 2.20 & 7.72 \\
\hline C.D at 5\% & 2.15 & 1.05 & 23.92 & 0.98 & ns & ns \\
\hline
\end{tabular}

Kashi Kranti $\left(\mathrm{V}_{1}\right)$, Kashi Pragati $\left(\mathrm{V}_{2}\right)$, and Pusa Sawani $\left(\mathrm{V}_{3}\right), 45 \times 30 \mathrm{~cm}\left(\mathrm{~S}_{1}\right), 45 \times 45 \mathrm{~cm}\left(\mathrm{~S}_{2}\right)$, and $45 \times 60 \mathrm{~cm}\left(\mathrm{~S}_{3}\right)$ 
In conclusion during the trail observation and after rigours analysis of data Variety $V_{2}$ (Kashi Pragati) perform well at spacing $(45 \times 45 \mathrm{~cm})$ in respect to total yield as compare to other variety and spacing. Branches are more seen when plant sown at wider spacing $(45 \times 60 \mathrm{~cm})$. There are so much parameter performs well at different spacing to different variety. In this experiment it is found that the number of seed per pod found better among close spacing $(45 \times 30 \mathrm{~cm})$ as compare to other spacing. Among different variety $\mathrm{V}_{1}$ (Kashi Kranti) produce more number of seed per pod as compare to other variety. Seeds weight of variety $\mathrm{V}_{3}$ (Pusa Sawani) better at wider spacing $(45 \times 60 \mathrm{~cm})$ as compare to other variety and spacing. At last it is concluded that spacing $(45 \times 45 \mathrm{~cm})$ are best spacing for okra sowing because the plant have get optimum space for proper growth, at spacing $(45 \times 30 \mathrm{~cm})$ there are competition for nutrient, light etc., at spacing $(45 \times 60 \mathrm{~cm})$ there lesser plant population ultimately yield are reduce. Variety $\mathrm{V}_{2}$ (Kashi Pragati) are perform better as compare to other variety. In respect of farmer benefit from this trail it is concluded that optimum spacing and verities play important role in benefit of farmer. Due to optimum spacing there are less competition between plant for nutrient, moisture, and light it also help in proper weeding between the plan and gets more yield. The cost of cultivation is also reduced so ultimately leads to enhanced profit.

\section{References}

Absar, N. and Siddique, M.A. 1982. Influence of plant density on the yield of three varieties of okra. Bangladesh Journal of Agriculture, 7(3/4): 15-21.

Adams, C.F., 1975. Nutritive value of American foods in common units, U.S. Department of Agriculture, Agriculture Handbook. 425, pp. 29.

Amjad, M., Sultan, M., Anjum, M.A. and Ayyub,
C.M. 2002. Response of okra (Abelmoschus esculentus) to various doses of $\mathrm{N}$ and $\mathrm{P}$ and different plant spacings. Pakistan Journal of Research sciences 13(1): 19-29.

Baw, A.O. 2014. Effects of plant population and nitrogen rates on growth and yield of okra [Abelmoschus esculentus (L.) Moench] in Gambella region, Western Ethiopia. M. Sc. Agri. Thesis (Unpublished) submitted to Haramaya University.

Dikwahal, H.D., Hoggai, P.T. and Aliyu, L. 2006. Effects of sowing date and plant population density on growth and yield of okra (Abelmoshcus esculentus $\mathrm{L}$ ) varieties in the northern guinea savanna of Nigeria. Nigerian Journal of Horticultural Science, 11(1): 56-62.

Ekwu, L.G. and Nwokwu. G.N., 2012. Effect of plant spacing and planting date on the growth and yield of okra [Abelmoschus esculentus (L.) Moench] in Abakaliki. International Journal of Agriculture and Rural Development, 15(2): 1041-1048.

El-Waraky and Y.B. 2014. Effect of sowing date, plant density and phosphorus fertilization on seed yield of okra. Alexandria Journal of Agricultural Science, 59(1): 27-41.

Firoz, Z.A., Islam, M.A., Mohiuddin, M. and Rahman, M.M. 2007. Yield and yield attributes of okra as influenced by planting time and plant spacing in hill slope condition. Progressive Agriculture, 18(2): 67-73.

Haytowitz, D.B. and Matthews, R.H. 1984. Mineral composition and nutrient in okra fruit in United States Department of Agriculture. Nutrition Monitoring Division; United States. Department of Agriculture. Human Nutrition Information Service.

Jana, J.C., Guha, S. and Chatterjee, R. 2016. Effect of planting geometry and nitrogen levels on crop growth, fruit yield and quality in okra grown during early winter in terai zone of West Bengal. Journal of Horticultural Science, 5(1): 30-33.

Khan, A.R. and Jaiswal, R.C. 1988. Effect of nitrogen, spacing and green fruit pickings on the seed production of okra [Abelmoschus esculentus (L.) Moench]. Vegetable Science, 15(1): 8-14.

Madisa, M.E., Mathowa, T., Mpofu, C. and 
Oganne, T.A. 2015. Effects of plant spacing on the growth, yield and yield components of okra (Abelmoschus esculentus L.) in Botswana. American Journal of Experimental Agriculture, 6(1): 7-14.

Martin, F.W. 1982. Okra, potential multiplepurpose crop for the temperate zones and tropics. Economic Botany, 36(3): 340-345.

Mondal, G., Malik, S.C. and Maity, T.K. 1989. Effect of sowing date and spacing on the growth and yield of okra. Crop Research, 2(2): 230-231

Palanisamy, V., Vanangamudi, K., Jayraj, T. and Karivarathraju, T.V. (1986). Influence of the date of sowing and spacing on seed quality in Bhindi. South Ind. Hort., 34(1): 23-25.

Parmar, P.N., Bhanvadia, A.S. and Chaudhary, M.M. 2015. Effect of spacing and nitrogen level on yield attributes, seed yield and economics of okra [Abelmoschus esculentus (L.) Moench] during kharif season under middle Gujrat conditions. Trends Biosciences, 8(8): 2160-2163.

Rehman, K. Khan S., Mohammad. N., Ibrahim, M. and Haq, I. 1994. Effect of different nitrogen levels and spacing on growth and yield of okra. Sarhad Journal of Agriculture, 10(2): 165-167.

Saha, P.K., Aditya, D.K. and Sharfuddin, A.F.M. 1989. Effect of plant spacing and picking interval on the growth and yield okra cv. Pusa Sawani. Bangladesh Horticulture, 17: 10-14.

Singh, B.P. 1990. Effect of spacing on okra. Indian Journal of Agronomy, 35(4): 439441.

Singh, K., Sarnaik, D.A. and Bisen, C.S. 1988. Effect of sowing dates and spacing on the yield and quality of okra seed [Abelmoschus esculentus (L.) Moench]. Research Development Reporter, 5(1-2): 83-86.
Singh, K.P., Malik, Y.S.; Lal, S. and Pandita, M.L. 1986. Eff

Singh, P.K., Singh, V.K., Singh, D.R. and Singh, P.N. 2012. Response of different levels of nitrogen, spacing and green fruit picking on growth, fruit yield, seed yield and seed quality of okra [Abelmoschus esculentus (L.) Moench]. Annals of Agricultural Research. New Series, 33(1 and 2): 36-39.

Sonu; Singh, J.P., Rajbeer, Nathiram and Kaushik, H. 2013. Effect of sowing dates and plant geometry on growth and yield of okra cv. Parbhai Kranti and Pus A4. Asian Journal of Horticulture, 8(2): 772-774

Steel, R.G.D. and Torrie, J.H., 1980. Principles and Procedures of Statistics, McGrawHill, Kogakusha, Tokyo, 633 pp.

Stoffella, P.J. and Bryan, H.H. 1988. Plant population influences growth and yields of bell pepper Journal of the American Society for Horticultural Science, 113: 835-839.

Vaidya, M.V. and Nanoti. 1989. Bhindi seed powder as coagulant in removal of turbidity from water. Indian Journal of Environmental Health, 31(1): 43-48.

Yadav, S.K. and Dhankar, B.S. 1999. Performance of Varsha Uphar cultivar of okra [Abelmoschus esculentus (L.) Moench] as affected by sowing dates and plant geometry. Vegetable Science, 26(2): 180182.

Yohanna, M.K., Garba, K.C., Kaki, N., Futuless, I.B., Mohammed, T. and Dishi, K. 2014. Effect of nitrogen and spacing on the performance of okra (Abelmoschus esculentus (L.) Moench) in Mubi, northern Guinea Savana Ecology, Nigeria. International Journal for Innovative Research Studies, 3(3): 325-333.

\section{How to cite this article:}

Pankaj Kumar Singh, A. K. Pal, Ajay Kumar Tiwari and Trivikram. 2020. Effect of spacings and varieties on yield attributes and fruit yield of Okra (Abelmoschus esculentus (L.) Moench.). Int.J.Curr.Microbiol.App.Sci. 9(08): 1196-1203. doi: https://doi.org/10.20546/ijcmas.2020.908.133 